\title{
Integrating local knowledge and science: economic consequences of driftwood harvest in a changing climate
}

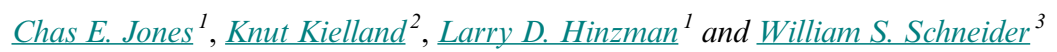

\begin{abstract}
The integration of local knowledge and science represents an opportunity to enhance the understanding of interrelations among climate, hydrology, and socioeconomic systems while providing mutual benefits to scientists and rural communities. Insight from rural Alaskans helped to identify a social-ecological threshold used to model potential driftwood harvest from the Yukon River. Information from residents of Tanana, Alaska, was combined with scientific data to model driftwood harvest rates. Modeling results estimated that between 1980 and 2010, hydrologic factors alone were responsible for a $29 \%$ decrease in the annual wood harvest, which approximately balanced a $23 \%$ reduction in wood demand because of a decline in number of households. The community's installation of wood-fired boilers in 2007 created a threshold increase $(76 \%)$ in wood demand that is not met by driftwood harvest. Modeling analyses of numerous climatic scenarios illustrated that increases in hydrologic variability would decrease the reliability of future driftwood harvest. Economic analyses demonstrated that increased climatic variability could have serious economic consequences for subsistence users while demanding more of their time. Lost time is important because it reduces their availability for performing other subsistence activities and learning to adapt to climate-related challenges. Our research may benefit communities by providing a tool that can be used to predict the timing and duration of driftwood runs. Information gathered from discussions with local stakeholders provided critical information for model development and thus provided a better understanding of regional social-ecological dynamics. Our research also illustrates the potential for regional-scale adaptations to limit the social-ecological impacts of environmental change, while providing economic opportunities and energy independence that reduce their vulnerability to variations in climate.
\end{abstract}

Key Words: biomass; climate; driftwood; economics; flood; hydrology; large woody debris; local knowledge; participatory research; socialecological model; threshold

\section{INTRODUCTION}

Residents of Tanana, Alaska, harvest driftwood during flood events on the Yukon River but have suggested that the driftwood harvest has been less reliable in recent decades. A participatory research approach uncovered linkages between climate, regional hydrology, and driftwood harvesting that help us to learn more about the impacts of a changing climate on society, while developing a tool that the community can use to predict the timing of driftwood runs.

Research that bridges the gap between local knowledge and science can provide reciprocal benefits to scientists and local communities (Huntington 2000, Carmack and Macdonald 2008, Weatherhead et al. 2010, Huntington et al. 2011). Traditional knowledge and local observations have been used in conjunction with scientific methods to gain a better understanding of how rural people rely on physical and natural phenomena (Krupnik and Jolly 2002, Chapin et al. 2006, Carmack and Macdonald 2008, Pearce et al. 2009, Weatherhead et al. 2010, Druckenmiller et al. 2013, Eicken et al. 2014). However, a desirable research objective would aim to produce tools or other research products that will also benefit local collaborators (Nadasdy 1999, Cruikshank 2001).

Rural Alaskans have witnessed many transformations during their lifetimes (Lovecraft and Eicken 2011, Schneider et al. 2013), but little of their traditional knowledge related to environmental changes has been recorded, cataloged, or integrated into scientific endeavors. However, local knowledge can complement scientific research by providing social context and illustrating the applicability of research (Berkes 1999, Cruikshank 2001, Weatherhead et al. 2010). Many scientific studies present evidence of changing environmental conditions in northern latitudes (Cullather et al. 2000, Yang et al. 2004, Hinzman et al. 2005, Prowse et al. 2007). However, it is less common to develop models based on local or traditional knowledge, although it is not unprecedented (Berman and Kofinas 2004, Berman et al. 2004, Nicolson et al. 2013).

Driftwood mobilization in the Yukon River is linked to river hydrology, and changes in discharge dynamics affect the availability of driftwood and the ability of rural Alaskans to harvest it as a resource. There is a trend toward increasing annual and summer discharge from the Yukon River basin because of increased glacial melt runoff, but flows are also affected by weather patterns associated with the Pacific Decadal Oscillation (Brabets et al. 2000, Brabets and Walvoord 2009). Conditions in Alaskan rivers are changing, e.g., ice conditions; timing of breakup and freeze-up; or the magnitude, timing, duration, or frequency of flood events (Hinzman et al. 2005, Walvoord and Striegl 2007, Brabets and Walvoord 2009, Ge et al. 2013), and they are projected to become more variable (ACIA 2005). Because rivers are integral to the subsistence lifestyles of rural Alaskans throughout the year (Wishart and Murray 2001, Alix and Koester 2002, Wheeler and Alix 2004), changing river character may impact social systems in rural Alaska.

Driftwood has always been very important to communities throughout Alaska (Alix and Koester 2002, Alix and Brewster 2004, Wheeler and Alix 2004, Alix 2005). In the western portion of the state, there is no large woody vegetation on the landscape, so driftwood has traditionally been the only source of large wood used as a fuel source and in construction. Now, wood for construction and fossil fuels are shipped to remote villages, and

${ }^{1}$ International Arctic Research Center, University of Alaska Fairbanks, ${ }^{2}$ Institute of Arctic Biology, University of Alaska Fairbanks, ${ }^{3}$ Oral History Department, University of Alaska Fairbanks 
fossil fuels have largely replaced wood for heating and power generation. As a heating fuel, oil is very reliable, and its acquisition demands less time than collecting wood. However, fuel oil is significantly more expensive and cannot be locally sourced. Thus, dependence on fossil fuels decreases the community's self-reliance and increases vulnerability to cost fluctuations or supply disturbances because of external factors beyond the community's control.

Increasingly, villages in rural Alaska are trying to lessen their dependence on fossil fuels by converting to biomass fuel sources (Fresco 2006, Fresco and Chapin 2009). The switch to biomass, a local and renewable fuel supply, is often driven by economics and a vision of self-reliance but has many other benefits. It strengthens the local economy, creates jobs, retains money locally, reduces fuel costs, and increases self-sufficiency, thereby reducing the village's vulnerability to external factors (Fresco 2006, Fresco and Chapin 2009). For the small city of Tanana, Alaska, the installation of wood-fired boilers in 2007 increased its annual demand for wood by approximately $76 \%$. If using only wood, the average household in Tanana requires approximately 7 cords (1 cord $=1.2 \mathrm{~m} \mathrm{x} 1.2 \mathrm{~m} \mathrm{x} 2.4 \mathrm{~m}$ ) of wood annually for home heating (A. Ketzler, T. Hyslop, C. Campbell, and C. Wright, personal communication), although the number of households has decreased from 113 in 1980 to 100 in 2010 (U.S. Census Bureau 1980, 2010). It should be noted that the municipality could use fuel oil if driftwood is not available. Although some households can utilize fuel oil as a backup, not all households have the appropriate infrastructure to burn fuel oil for heating.

The hydrograph for the Yukon River at Stevens Village, $200 \mathrm{~km}$ upstream from the city of Tanana (Fig. 1), shows the typical occurrence of a spring breakup peak in mid-May and a predictable pulse of high water, commonly referred to as the "June rise," that follows weeks later in early June (Fig. 2). During most summers, large quantities of driftwood are carried by the Yukon River during the two distinct high-flow events. During the spring breakup, driftwood accompanies rafts of river ice during high flows. A few weeks later in early June, the June rise also carries high volumes of driftwood, but the absence of the associated river ice makes the wood more accessible and safer to collect. Driftwood is typically mobilized while the river stage is rising and is deposited when the water levels decrease or when wind or water currents push the wood ashore. While the Yukon River driftwood is mobilized, it is transported downstream. Tanana residents use boats to travel upstream to harvest floating driftwood. Harvesting mobilized driftwood requires the roots to be removed before transporting individual or rafts of logs back to town. The wood is collected for personal use, sold to other Tanana residents, or sold to the village or local tribal government. Its predictable nature, ease of access, and cost-effectiveness make driftwood the preferred wood source for Tanana and other Alaskan communities.

During a community meeting in spring 2011, Tanana residents discussed how river conditions have changed in recent decades. As evidence, they described the flood patterns and associated driftwood runs of 2009 and 2010 as unusual, although not unique. They associated driftwood supply to river hydrology and the challenges inherent in its acquisition. The magnitude of the 2009 Yukon River spring breakup flood was discussed because it
Fig. 1. Study area map of Tanana, Alaska, and vicinity. (A) The regional location of Alaska relative to Canada, Russia, and the contiguous United States. (B) The Yukon and Tanana River watersheds within Alaska. (C) The locations of the communities of Fairbanks, Nenana, Tanana, and Stevens Village relative to the Yukon and Tanana Rivers.

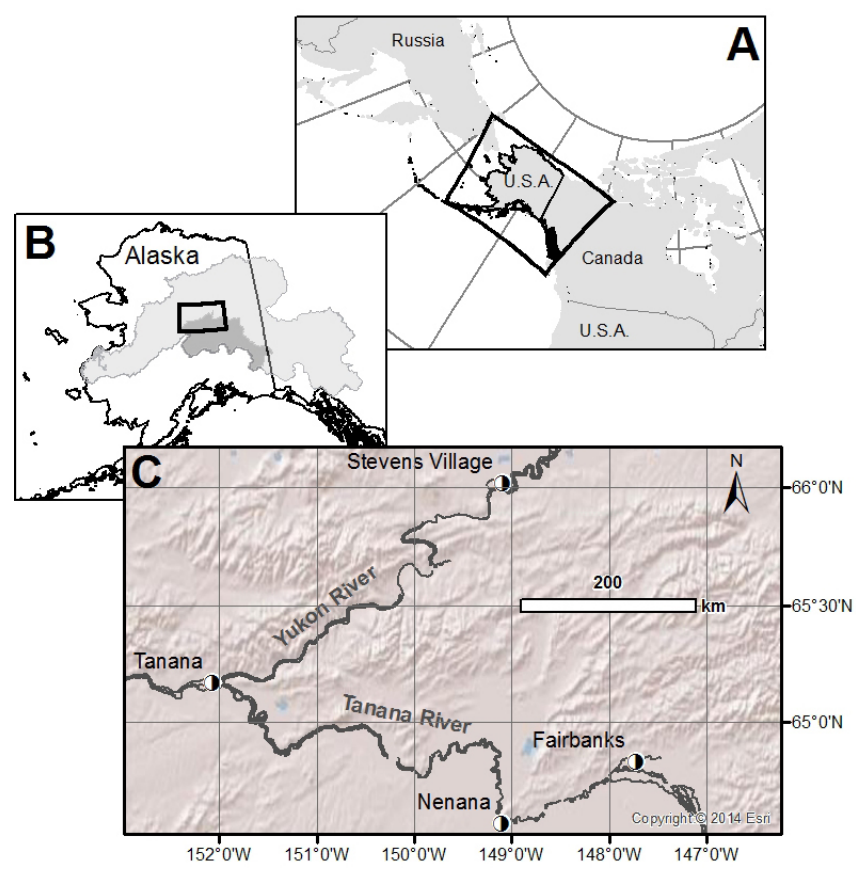

Fig. 2. Average monthly discharge of the Yukon River at Stevens Village, Alaska, gauging station for 1977 to 2012 illustrates the typical spring breakup flood and the larger "June rise" that occurs soon after spring breakup. The driftwood mobilization threshold is also depicted. Figure based on data from U.S. Geological Survey gauging station for Yukon River at Stevens Village.

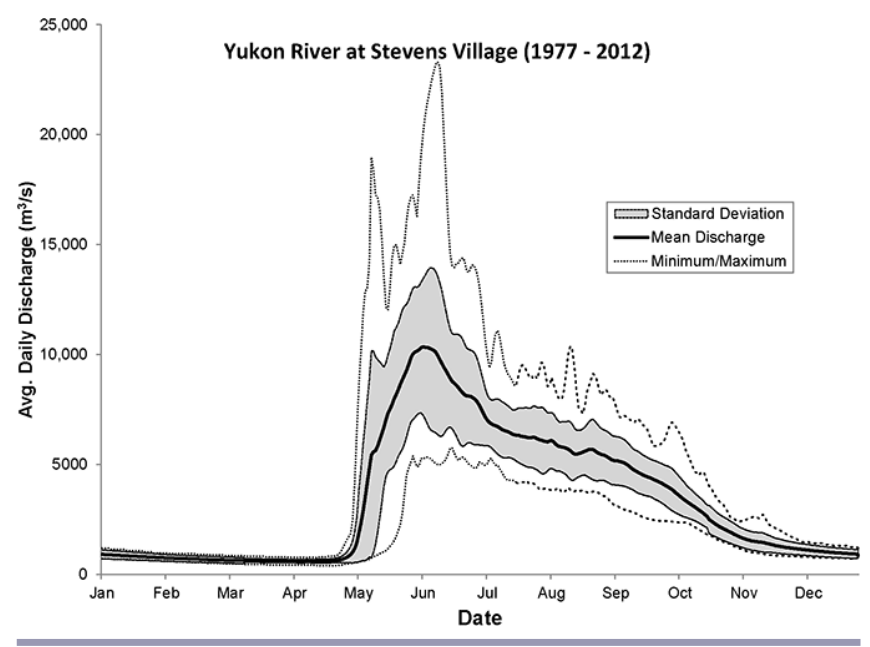


caused substantial damage in communities along the river, including the community of Tanana. The high water levels, which reportedly washed much of the driftwood from the river, were blamed for a bad driftwood harvest.

Residents also discussed the 2010 driftwood season. In mid-May, spring breakup flooding was normal, but the June rise never materialized. After several weeks, the community became concerned that no driftwood had come downriver. In mid-July, residents' wood stacks were small, berry-picking season had started, and the fishing season was going strong. Even the municipal wood supply was meager. Since the installation of the wood-fired boilers, the local city and tribal governments have purchased 400-1000 cords of driftwood annually from locals (A. Ketzler, personal communication). According to Ruth Althoff (personal communication), "finally in late-July, the river came up, but there was no wood, and then the river came up higher in midAugust and finally, there came the wood."

In-person interviews, recorded interviews, and a community meeting were conducted in Tanana to reveal that in recent decades, high-flow events that carry driftwood have become less predictable (Schneider et al. 2013). Variability in flood frequency, magnitude, duration, or timing affect driftwood flows in the river and the ability of Tanana residents to harvest it as a subsistence resource. These types of changes in river hydrology threaten their access to driftwood and require the use of alternative fuels that may be more costly or time intensive. Fuel oil is a readily available, but costly fuel alternative that demands less time relative to the wood options. Standing deadwood comprises dead standing trees harvested by residents in the winter using snowmobiles and sleds. Stranded driftwood is wood previously mobilized by the river and deposited on the riverbank, but accessible only in summer when not frozen in the mud or covered in snow. The source of standing deadwood varies over time, but the typical harvest technique often involves traveling over land and ice with snowmobile and sled to recently burned areas or forest groves that have been killed and maintained as potential wood sources. Stranded driftwood can require extensive effort to harvest and transport to town. Harvesters of stranded driftwood are likely to harvest from stretches of river relatively near Tanana. The advantage of standing deadwood is that it usually has a lower moisture content, but individual logs are typically smaller in diameter.

Because of the participatory process, the concerns of Tanana residents motivated a series of research questions that required incorporating local knowledge into the scientific process. To generate a better understanding of the social-ecological system, five research questions were examined:

1. What are the magnitudes of changes in the timing and frequency of peak flow events?

2. Are there changes in hydrology that correlate to reported observations regarding the driftwood harvest by Tanana residents?

3. How has the potential driftwood harvest been affected by changes in river hydrology?

4. How might the driftwood harvest be affected by future changes in river hydrology?

5. What are the estimated costs, i.e., time and financial, associated with changes in the potential driftwood harvest?

\section{METHODS}

\section{Study area}

Tanana is a small community, with an approximate population of 300 people in 100 households (U.S. Census Bureau 2010), located on the north bank of the Yukon River, $3.3 \mathrm{~km}$ downstream from the confluence of the Yukon and Tanana Rivers in the state of Alaska (Fig. 1). Its economy depends heavily on subsistence activities, i.e., hunting, fishing, and gathering. The positioning of islands in the river ensures that most driftwood from the Tanana River, which enters from the south, is not easily accessible to Tanana residents; therefore, harvested driftwood originates primarily in the Yukon River (C. Wright and C. Campbell, personal communication).

The Yukon River is a glacierized basin, with 59\% (508,400 $\left.\mathrm{km}^{2}\right)$ of the catchment area above the Stevens Village gauge. Less than $1 \%$ of the catchment above the gauge is glaciated (Brabets et al. 2000). The hydrology of the Yukon River is dominated by the spring melt and breakup. The spring breakup can be rather violent, which may relate to the physiographic orientation of the watershed. Water in the upper basin flows from south to north and breaks up in warmer southern areas before flowing north where the river ice is still stable. The majority of the summer discharge results from snowmelt, rainfall, and glacial melt (Brabets et al. 2000).

\section{Local knowledge}

After reviewing recorded interviews of six Tanana residents (Schneider et al. 2013), a local Tanana resident organized a community meeting, hosted by the University of Alaska Fairbanks, on the subject of changing river conditions in March 2011. Eighteen community residents came to the meeting and shared stories and observations relating to the river. The community meeting was not focused on the harvest or use of driftwood; however, it became apparent that driftwood was an issue of concern for Tanana residents. Follow-up discussions were initiated with the meeting participants who had concerns about the driftwood harvest. Additional interviews were held with residents based on referrals. Follow-up discussions involved semiformal unrecorded interviews during which open-ended questions were asked about flooding, driftwood harvest, driftwood processing, wood use, fuel oil consumption, and related topics. The interview subjects included two individuals who harvest and sell wood locally, three individuals who harvest wood for personal use, and the city manager who championed the installation of the city's wood-fired boilers and developed the incentives program facilitating the purchase and sales of harvested wood. The interviewers did not make an effort to solicit participation based on demographic criteria but sought participation from community members considered local experts on harvesting driftwood or the driftwood economy in the city of Tanana. Follow-up interviews were used to resolve discrepancies between interview subjects. Minor differences between responses were averaged across interviewees to avoid subjective assessment of respondent accuracies. There were no substantive differences between interviewee responses.

\section{Driftwood mobilization threshold}

Based on local knowledge and subsistence records, a "driftwood mobilization threshold" was identified. Above this discharge, unlimited driftwood was assumed to be mobilized by the river until the discharge peaks. To develop this threshold value, 
interview data from 2009 and 2010 (see Introduction) were related to the U.S. Geological Survey (USGS) gauging station data at Stevens Village. Additionally, one longtime Tanana resident kept records of his subsistence activities associated with the driftwood harvest since 1989 (Table 1). During an informal interview, he shared his driftwood records. The records include the date, the number of logs harvested, and relevant notes. The discharge at Stevens Village 2 days prior to the harvest date, the approximate conveyance period between Stevens Village and Tanana, was analyzed and compared to the interview data associated with the 2010 hydrologic year to validate the concept of a driftwood mobilization threshold.

Table 1. Driftwood records kept by calendar year. Records kept by Mr. Tom Hyslop (Tanana, Alaska).

\begin{tabular}{lcl}
\hline \hline $\begin{array}{l}\text { Harvest } \\
\text { date }\end{array}$ & Number of logs & Notes \\
\hline $6 / 3 / 1989$ & 29 & \\
$5 / 23 / 1990$ & 6 & Calendar not found \\
$5 / 1 / 1991$ & - & Calendar not found \\
$5 / 1 / 1992$ & - & Low water year \\
$5 / 1 / 1993$ & 0 & Low water year \\
$5 / 1 / 1994$ & 0 & Low water year \\
$5 / 1 / 1995$ & 0 & Calendar not found \\
$5 / 1 / 1996$ & - & Calendar not found \\
$5 / 1 / 1997$ & - & Calendar not found \\
$5 / 1 / 1998$ & - & \\
$6 / 1 / 1999$ & - & \\
$5 / 29 / 2000$ & 46 & Calendar not found \\
$6 / 11 / 2001$ & 36 & \\
$6 / 1 / 2002$ & - & \\
$6 / 5 / 2003$ & 35 & Calendar not found \\
$5 / 23 / 2004$ & 21 & Calendar found - no records \\
$5 / 15 / 2005$ & 22 & Small logs \\
$5 / 1 / 2006$ & & Big flood \\
$6 / 1 / 2007$ & - & Huge driftwood run \\
$5 / 24 / 2008$ & 20 & Calendar not found \\
$5 / 11 / 2009$ & 0 & \\
$8 / 13 / 2010$ & 14 & \\
$5 / 28 / 2011$ & - & \\
$5 / 1 / 2012$ & & \\
& & \\
\hline
\end{tabular}

Tanana residents suggested that driftwood from the Tanana River is silt laden and less desirable to use as firewood. In addition, driftwood from the Tanana River typically flows on the far side of islands in the Yukon River near the community. Therefore, only hydrologic data for the Yukon River were analyzed, despite the fact that driftwood in the Tanana River, which is hydrologically influenced by glaciers, would be mobilized independent of the timing of driftwood runs in the Yukon River.

\section{Hydrologic variability}

River discharge data were analyzed to determine whether changes in hydrology reported by Tanana residents correspond to records from the USGS Stevens Village gauging station, which is the next gauging station upstream on the Yukon River. Peak annual discharge data were analyzed for the period of record (1977-2013) to determine the Log-Pearson Flood Flow Frequency, using the Log-Pearson Flood Flow Frequency from USGS 17B MATLAB extension. The average daily discharge was used to analyze the number of years that small floods, i.e., <1.25-year recurrence interval, were not realized in a given year. The hydrographic record was separated into early (1977-1993) and late (1994-2013) phases based on the analysis of small floods.

For each phase, the first two flood peaks of the year were categorized as associated with the spring breakup, June rise or post-breakup flood peak that exceeds the driftwood mobilization threshold, or other. For each flood peak, the day of year, magnitude, and duration of the rising limb of the hydrograph were determined. The data were summarized for each year of the period of record.

\section{Driftwood harvest model}

Interviews and census data were used to develop model parameters (Table 2) for calculations of the annual village wood harvest $\left(\mathrm{H}_{\text {annual }}\right.$, Eq. 1), demand ( $\mathrm{D}_{\text {annual }}$, Eq. 2$)$, and deficit (Def ${ }_{\text {annual }}$, Eq. 3). The annual driftwood harvest was estimated from the number of households in Tanana $\left(\mathrm{n}_{\mathrm{HH}}\right)$, the percentage of households harvesting driftwood $\left(\%_{\mathrm{HH}}\right)$, the harvest rate $\left(d \mathrm{H}_{\mathrm{HH}} / d \mathrm{t}\right)$, and the annual number of driftwood days $\left(\mathrm{t}_{\mathrm{w}}\right)$. The annual village demand was the sum of the municipal demand $\left(D_{M}\right)$ and the number of households multiplied by the average household demand $\left(\mathrm{D}_{\mathrm{HH}}\right)$ for wood. The total municipal demand would provide $100 \%$ of the heating wood supply for the village. The deficit is the difference between $\mathrm{D}_{\text {annual }}$ and $\mathrm{H}_{\text {annual }}$.

$$
\begin{gathered}
\mathrm{H}_{\text {annual }}=\%_{\mathrm{HH}} \mathrm{n}_{\mathrm{HH}}\left(\frac{d \mathrm{H}_{\mathrm{HH}}}{d \mathrm{t}}\right) d \mathrm{t}_{\mathrm{w}} \\
\mathrm{D}_{\text {annual }}=\mathrm{n}_{\mathrm{HH}} \mathrm{D}_{\mathrm{HH}}+\mathrm{D}_{\mathrm{M}} \\
\text { Def }_{\text {annual }}=\mathrm{H}_{\text {annual }}-\mathrm{D}_{\text {annual }}
\end{gathered}
$$

\section{Driftwood harvest in a changing climate}

To understand how an increasingly variable climate may influence Tanana's driftwood harvest, scenarios were developed to examine the potential response of the driftwood harvest to increasing variability in the annual number of driftwood days. Assuming that changes in variability in the 1994-2013 phase represent a directional change from the 1977-1993 phase (ACIA 2005, AMAP 2011), the observed variability was increased by factors of $0,1,2$, and 3 to assess the impacts of climate variability on the driftwood harvest. Thus, the 1977-1993 data set is referred to as the 0x scenario, the 1994-2013 data set is referenced as the 1x scenario, and the $2 \mathrm{x}$ and $3 \mathrm{x}$ scenarios are assumed to have double and triple the variability observed between the $0 \mathrm{x}$ and $1 \mathrm{x}$ scenarios. To assess the variability of the different scenarios, Easyfit (v5.5) was used to perform the Anderson Darling test ( $p$ $<0.01$ ) to determine that the distribution of annual driftwood days for the period of record could be best represented by a geometric probability density function (pdf) for discrete data: $f$ $(\mathrm{x} ; \mathrm{q})=\mathrm{q}(1-\mathrm{q})^{\mathrm{x}}$ for $\mathrm{x} \geq 0, \mathrm{q}=0.11859$. The early (1977-1993) and late (1994-2013) phase data sets were then fit to geometric distributions: $\mathrm{q}_{0 \mathrm{x}}=0.11258$ and $\mathrm{q}_{1 \mathrm{x}}=0.12422$, respectively. Assuming the 1977-1993 distribution as a benchmark, i.e., 0x scenario with $\mathrm{q}_{0 \mathrm{x}}$ and variance $\left(\sigma^{2}\right)$ of $70.02\left(\sigma^{2}=[1-\mathrm{q}] / \mathrm{q}^{2}\right)$, the difference between $\sigma^{2}$ of the $0 \mathrm{x}$ and $1 \mathrm{x}$ scenarios was multiplied by $0,1,2$, and 3 and added to the benchmark to derive the desired 
Table 2. Parameters used in the driftwood harvest model.

\begin{tabular}{|c|c|c|c|}
\hline Parameter & Variable & Value & Source \\
\hline Number of village households & $\mathrm{n}_{\mathrm{HH}}$ & $\begin{array}{l}\text { Estimated: } \\
\text { 1977-1993: } 113 \text { households } \\
\text { 1994-2013: } 100 \text { households }\end{array}$ & $\begin{array}{l}\text { 1977-1993: U.S. Census Bureau (1980), } \\
\text { 1994-2013: U.S. Census Bureau (2010) }\end{array}$ \\
\hline $\begin{array}{l}\text { Percentage of village households } \\
\text { harvesting driftwood each driftwood } \\
\text { day }\end{array}$ & ${ }^{\%}{ }_{\mathrm{HH}}$ & Assumed: $10 \%$ & $\begin{array}{l}\text { Interviews: Charlie Wright, Charlie Campbell, } \\
\text { Alfred Ketzler }\end{array}$ \\
\hline $\begin{array}{l}\text { Average daily rate of driftwood } \\
\text { harvest }\end{array}$ & $d \mathrm{H}_{\mathrm{HH}} / d \mathrm{t}$ & $\begin{array}{l}\text { Assumed: } 2 \text { cords per driftwood day per } \\
\text { household }\end{array}$ & $\begin{array}{l}\text { Interviews: Charlie Wright, Charlie Campbell, } \\
\text { Alfred Ketzler }\end{array}$ \\
\hline Average annual household demand & $\mathrm{D}_{\mathrm{HH}}$ & Assumed: 7 cords per household per year & $\begin{array}{l}\text { Interviews: Charlie Wright, Charlie Campbell, } \\
\text { Alfred Ketzler, Tom Hyslop }\end{array}$ \\
\hline $\begin{array}{l}\text { Average annual municipal wood } \\
\text { demand }\end{array}$ & $\mathrm{D}_{\mathrm{M}}$ & $\begin{array}{l}\text { Assumed: } \\
\text { 1977-2006: } 0 \text { cords } \\
\text { 2007-2013: } 300 \text { cords }\end{array}$ & Interview: Alfred Ketzler \\
\hline $\begin{array}{l}\text { Driftwood days } \\
\text { Total annual driftwood harvest } \\
\text { Total annual village wood demand } \\
\text { Potential annual driftwood deficit }\end{array}$ & $\begin{array}{l}\mathrm{t}_{\mathrm{w}} \\
\mathrm{H}_{\text {annual }} \\
\mathrm{D}_{\text {annual }} \\
\text { Def } \\
\text { annual }\end{array}$ & $\begin{array}{l}\text { Calculated } \\
\text { Calculated } \\
\text { Calculated } \\
\text { Calculated }\end{array}$ & Interviews, USGS gauging station data \\
\hline
\end{tabular}

variance of geometric pdfs for each scenario. The value of $q$ was determined to provide the desired pdf, i.e., $\mathrm{q}_{0 \mathrm{x}}=0.11258, \mathrm{q}_{1 \mathrm{x}}=$ $0.12422, \mathrm{q}_{2 \mathrm{x}}=0.14058$, and $\mathrm{q}_{3 \mathrm{x}}=0.16610$, from which 1000 random points were generated to define the $0 \mathrm{x}-3 \mathrm{x}$ scenarios. These data represent the annual number of driftwood days for each scenario, which were used as input in the driftwood harvest model. The model output estimates the annual harvest and deficit based on annual driftwood days, while considering the increased demand for fuel wood since 2007 and the installation of additional wood-fired boilers in 2013, increasing demand by an estimated 98 cords of wood annually.

\section{Economic analyses}

The costs, i.e., financial and time, associated with the harvest and use of substitute fuels were assessed when insufficient driftwood was harvested to meet the city's needs. Costs were estimated using a linear activity analysis model using fixed-input parameters based on interviews. The percentage of each fuel type used to meet the city's total wood deficit was modified for each assessment. Five assessments were modeled based on the approximate 1994-2013 deficit. During that time, the driftwood harvest model estimated an average deficit of 903 cords annually. Each assessment calculates the costs associated with using alternate fuels for the deficit. The costs are calculated for the following situations to meet the deficit: harvesting driftwood, mobilized by the river, if it was available; harvesting stranded driftwood from riverbanks; collecting standing deadwood as the wood substitute; using only fuel oil; and using a mix of alternative fuels for the driftwood deficit, i.e., $25 \%$ stranded driftwood, $25 \%$ standing deadwood, and $50 \%$ fuel oil. The full activity analysis model is described in Appendix 1 and estimates the temporal and financial costs associated with each situation.

\section{RESULTS}

\section{Hydrologic variability}

The magnitudes of flood recurrence intervals were determined for the Yukon River at Stevens Village for the period of record and separately for the early and late phases of the record (Table
3). From 1977 to 1993 , the annual peak discharge failed to exceed the 1.25 -year flood event $\left(11,000 \mathrm{~m}^{3} / \mathrm{s}\right.$ [cms]) in only 1 out of 17 years ( $5 \%$ of the years), but from 1994 to 2013, this threshold was not reached in $25 \%$ of the years (5 out of 20 years). A one-tailed Student $t$ test assuming unequal variance verifies that the peak annual discharge is significantly different $(p<0.05)$ between phases.

Table 3. Calculated flood recurrence intervals, rounded to nearest $100 \mathrm{~m}^{3} / \mathrm{s}$, for the Yukon River at Stevens Village for 2 phases of the period of record and the entire 37 years of data.

\begin{tabular}{lccc}
\hline \hline $\begin{array}{l}\text { Flood Recurrence } \\
\text { Interval (years) }\end{array}$ & $1977-1993$ & $1994-2013$ & $1977-2013$ \\
\hline 1.01 & 9400 & 7600 & 8200 \\
1.25 & 12,000 & 10,300 & 11,000 \\
2 & 13,100 & 11,400 & 12,100 \\
5 & 14,500 & 12,600 & 13,500 \\
10 & 18,200 & 15,600 & 16,900 \\
25 & 20,800 & 17,500 & 19,300 \\
50 & 23,500 & 19,400 & 21,500 \\
100 & 24,400 & 20,000 & 22,300 \\
& & & \\
\hline
\end{tabular}

There was no significant difference between the dates of the spring breakup peak between the early or late phases. Additionally, the median date of the secondary flood peak that exceeds the driftwood mobilization threshold is similar between the two periods. However, the variability for the recent period after 1993 (standard deviation $[\mathrm{SD}]=25$ days) is much greater than the period prior ( $\mathrm{SD}=7$ days).

\section{Local knowledge and driftwood mobilization threshold}

According to Mrs. Althoff (personal communication), in August 2010, the river exceeded flows of the previous 2 months and carried driftwood with it. This information was used in conjunction with USGS discharge data to determine that a flow at Stevens Village between 8800 and $10,500 \mathrm{cms}$ mobilized large 
amounts of driftwood. Mr. Hyslop's subsistence records (Table 1) were also analyzed in conjunction with USGS river discharge data. Two days, i.e., the approximate conveyance time of flow between Stevens Village and Tanana, before the date Mr. Hyslop caught driftwood in any given year, the discharge at Stevens Village averaged $10,000 \mathrm{cms}(\mathrm{SD}=2100 \mathrm{cms})$, which is between the upper and lower threshold estimates derived from Mrs. Althoff's story regarding the 2010 driftwood season. Both analyses support the concept of a driftwood mobilization threshold at a discharge of $10,000 \mathrm{cms}$ (Fig. 2). Above this discharge, unlimited driftwood is assumed to be mobilized by the river until the discharge peaks.

Residents also suggest that the driftwood harvest runs have become shorter. One resident stated that residents may have just 1-3 days to harvest driftwood, whereas historically the driftwood run lasted 4-5 days (Schneider et al. 2013).

\section{Driftwood harvest model}

Figure 3 illustrates that the modeled driftwood harvest for Tanana was more variable in most years since 1993, while extremes did occur in the earlier phase. According to the model, variations in river hydrology combined with increased municipal demand and decreased cumulative household demand result in an increasing annual wood deficit for Tanana (Fig. 4).

Fig. 3. The minimum, 25th percentile, median, 75 th percentile, and maximum potential driftwood harvest for the early and late phases of the period of record depict small expected harvest volumes in the future.

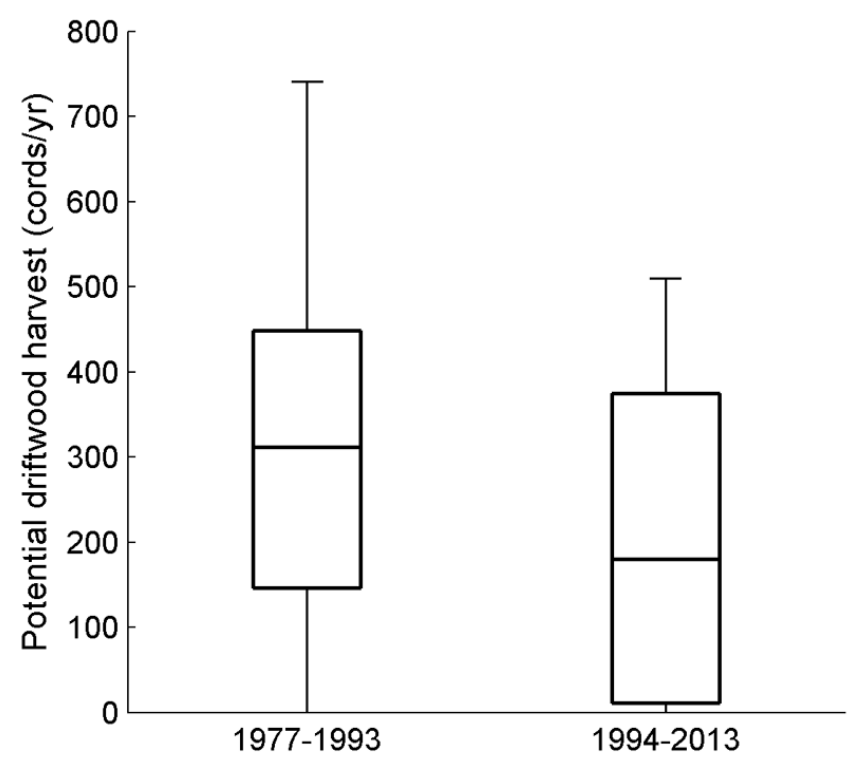

Although modeling predicts that it has been always been necessary to supplement the driftwood harvest, $44 \%$ of wood demand was met with only mobilized driftwood from 1977 to 1993. Between 1994 and 2006, prior to installation of municipal wood-fired boilers, $42 \%$ of wood demand was met with mobilized driftwood. After 2000, a smaller number of households in the city, i.e., a decrease from 113 to 100 households, reduced the wood demand by $23 \%$, although the installation of the city's wood-fired boilers in 2007 subsequently increased demand by $76 \%$. Therefore, after 2007 , the average harvest was only $21 \%$ of city's total wood demand. Thus, despite an average decrease in the modeled annual harvest of $29 \%$ because of hydrologic factors alone, the average wood deficit ( 730 cords) after 2007 was $90 \%$ greater than before 1993 and was 140\% higher than the period between 1994 and 2006 (Fig. 4).

Fig. 4. The estimated driftwood deficit for Tanana illustrates that the increased demand for wood after 2007 had a large impact on the amount of wood available in the village.

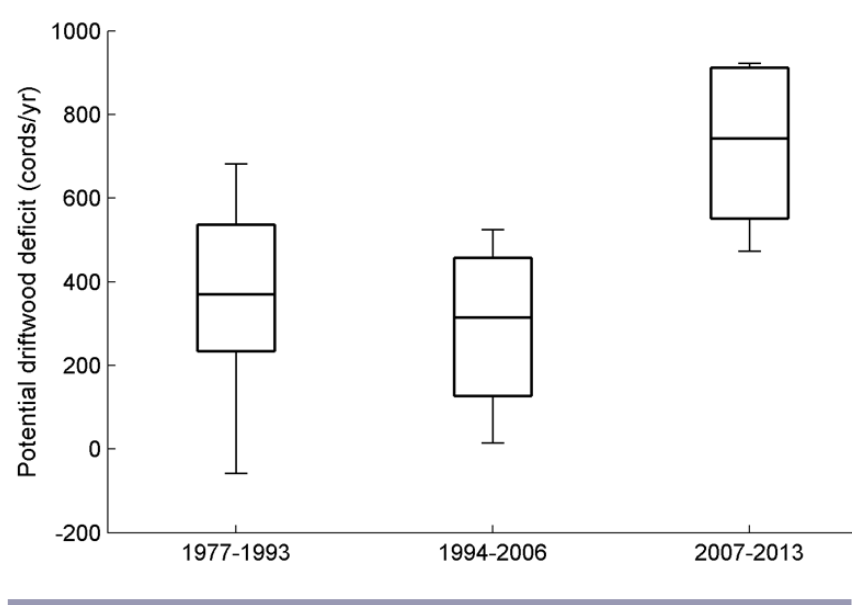

Driftwood harvest in a changing climate

With increasing variance in the exponential distribution of driftwood days, there were more years with no driftwood days (Fig. 5); thus, the median number of driftwood days decreased (Table 4). Similarly, the median driftwood harvest is modeled to become smaller. Thus, in scenarios with more variability, the median deficit is projected to become greater (Table 4).

Fig. 5. The observed frequency, for all years, and expected probability of occurrence of the annual number of driftwood days under 4 scenarios, $0 \mathrm{x}-3 \mathrm{x}$, with increasing variability from the observed data.

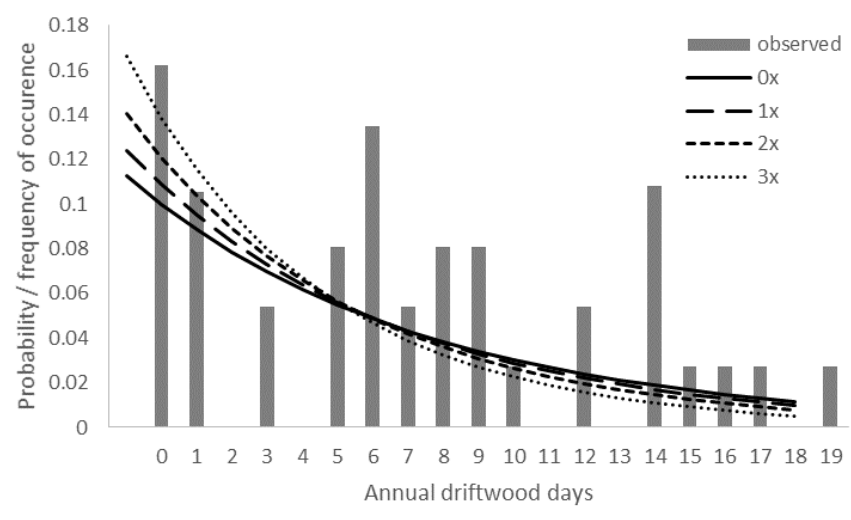


Table 4. Climate variability scenarios: parameter definition and results summary.

\begin{tabular}{|c|c|c|c|c|c|}
\hline \multirow[t]{2}{*}{ Parameter } & \multirow[t]{2}{*}{ Statistic } & \multicolumn{4}{|c|}{ Climate Scenario } \\
\hline & & $0 \mathrm{x}$ & $1 \mathrm{x}$ & $2 \mathrm{x}$ & $3 x$ \\
\hline \multirow[t]{3}{*}{ Driftwood days } & $25 \%$ & 2.0 & 2.0 & 1.0 & 1.0 \\
\hline & $50 \%$ & 5.0 & 5.0 & 4.0 & 3.5 \\
\hline & $75 \%$ & 10.0 & 9.0 & 8.0 & 7.0 \\
\hline \multirow[t]{3}{*}{ Driftwood harvest (cords) } & $25 \%$ & 60 & 60 & 30 & 30 \\
\hline & $50 \%$ & 150 & 150 & 120 & 105 \\
\hline & $75 \%$ & 300 & 270 & 240 & 210 \\
\hline \multirow[t]{3}{*}{ Driftwood deficit (cords) } & $25 \%$ & 235 & 384 & 385 & 535 \\
\hline & $50 \%$ & 865 & 865 & 895 & 910 \\
\hline & $75 \%$ & 955 & 955 & 985 & 985 \\
\hline
\end{tabular}

\section{Economic analyses}

There is an inverse relationship between the economic costs and time investment for the use of each alternative fuel type to meet the energy needs associated with the average modeled driftwood deficit from 1994 to 2013 (Fig. 6). The harvest of standing deadwood is modeled to require the least amount of money, but additional time compared to driftwood. The use of only fuel oil saves a substantial amount of time over all wood options, i.e., 9000-15,000 hours annually, but there are substantial costs associated with fuel oil, i.e., approximately $\$ 533,000$ for the whole community. Results illustrated that a mix of alternative fuels, i.e., fuel equivalent of the modeled wood deficit substituted with $25 \%$ stranded driftwood, 25\% standing deadwood, and 50\% fuel oil, balances the monetary and temporal costs of each alternative. In addition, based on the economics model, the time associated with the harvest of driftwood equates to a value of US\$36.00 to US\$59.00 per hour.

\section{DISCUSSION}

\section{Local knowledge}

Our research originated from a public meeting where residents of Tanana reported that the driftwood harvest had become less reliable in recent decades. They discussed how they typically harvested driftwood during the June rise, a relatively predictable rise in the hydrograph in early June, but the June rise was not occurring with the same regularity to which they were accustomed. Our results support this observation by showing that the timing of flood peaks not associated with spring breakup, yet sufficient to mobilize driftwood, has become more variable since 1994. There is some evidence that June rise events are initiated by precipitation events in portions of the upper watershed. Interviewees also suggest this linkage, but additional research on the subject may provide insight into the drivers of the June rise.

\section{Driftwood mobilization threshold}

Through the participatory research process, it was determined that once the river stage exceeds a driftwood mobilization threshold, driftwood becomes readily available for harvest. This is an illustration of how different types of knowledge, i.e., scientific data and local knowledge, may be integrated to study a phenomenon. In this case, the context of the information was related to river hydrology to identify a "driftwood mobilization threshold," a level of river discharge that once exceeded mobilizes driftwood until the river discharge peaks.
Fig. 6. Estimated costs, i.e., financial and time, associated with the harvest of the average modeled wood deficit, 730 cords, from 2007 to 2013 using each fuel type alone versus a mix of $25 \%$ stranded driftwood, $25 \%$ standing deadwood, and $50 \%$ fuel oil. The size of the bubble is proportional to the estimated financial cost, rounded to the nearest $\$ 100$ U.S. dollars. Time costs include the time required to gather and process wood.

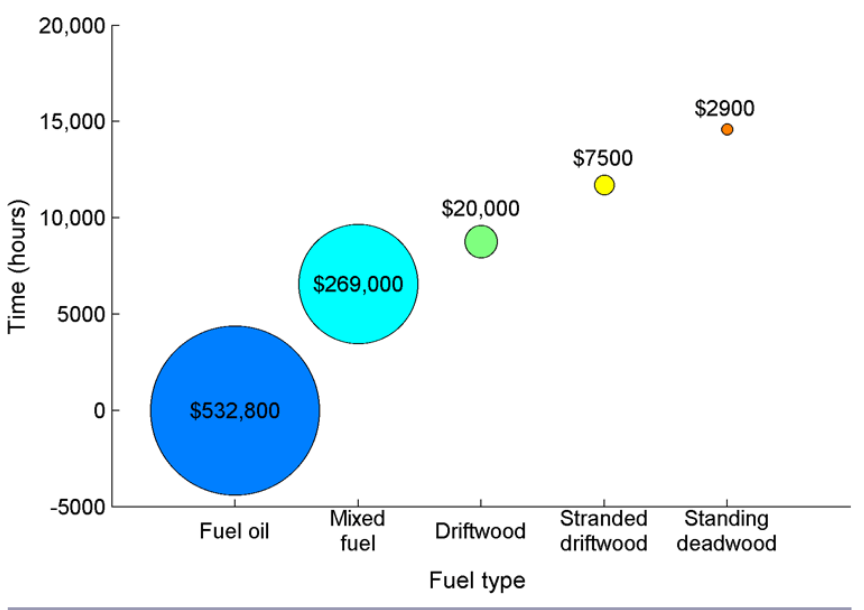

The concept of a driftwood mobilization threshold was used as a simple representation of a complex system to develop a driftwood harvest model. The concept has limitations in its applicability because an increasing demand for wood eventually results in limitations in the available driftwood supply for downstream villages. Conversely, if upstream villages start using more wood, the wood available in Tanana could be reduced. Driftwood is differentially distributed in space and time throughout the river. Despite these limitations, increasing amounts of driftwood are mobilized as the river discharge increases during the spring melt. Initially, the amount of mobilized driftwood rises with increasing discharge, with the amount of mobilized wood leveling off as the river reaches the flood stage and spills onto the floodplain. Additionally, driftwood is deposited on riverbanks at river bends, during periods of high wind, and as water levels fall. Storm intensity, flood history, and fire history in the watershed also affect the bank erosion and the associated wood deposition into the river channel (Mason 1998, Yarie et al. 1998, Ott 2000, Ott et al. 2001, Alix 2005, Rowland et al. 2010). 
It would be worthwhile to examine relationships between high flows, bank erosion, and the deposition of wood into the river channel. Typically, episodic erosion of the riverbank occurs during high river stages (Yarie et al. 1998) and causes wood to fall into the channel (Ott 2000, Ott et al. 2001). Areas where the vegetative armoring is compromised, such as areas of recent forest fires, are more prone to bank erosion and the associated deposition of wood into the channel (Ott 2000, Ott et al. 2001). An analysis of the movement and life cycles of driftwood in the Yukon River watershed would provide valuable information about its ecology and social-ecological importance in the Yukon. Such analyses may inform the state of Alaska and villages along the Yukon River about the sustainable harvest capacity of driftwood from the Yukon River watershed, which may become an issue if more communities increase their harvest of driftwood.

When the community of Tanana installed its wood-fired boilers in 2007 , the fuel wood demand increased by $76 \%$ and raised the community fuel wood deficit (Fig. 4). Because hydrologic factors were responsible for a $29 \%$ decrease in the driftwood harvest and the decreased number of households reduced wood demand by $23 \%$, the model indicates that the increased municipal demand for wood had a much greater effect on the total wood consumption compared to changes in hydrology or population.

The number of days that the river exceeds the driftwood mobilization threshold is greater than the number of days that locals suggest that driftwood is available in a given year. According to the model, the mean number of annual driftwood days was 7.4 days since 1977 and was not different between the early and late phases of the study period. Local residents suggest that the number of driftwood days has decreased from 4-5 to 1-3 in recent decades. This discrepancy may be founded in either the use of local knowledge or the concept of a driftwood mobilization threshold. It is likely a combination of both.

\section{Driftwood harvest in a changing climate}

The model corroborates local reports of a less reliable driftwood harvest in recent decades. According to interviews about the potential rates of wood harvest and the number of households harvesting driftwood, historically Tanana needed an estimated 23 driftwood days to harvest its annual wood demand, whereas since 2007 an estimated 35 driftwood days are needed annually. Historically, Tanana could expect to meet $8-35 \%$ of its heating fuel needs using driftwood. Since 2007, the average modeled harvest would meet $15 \%$ of Tanana's wood requirements, and the city could reasonably expect to obtain between $7 \%$ and $31 \%$ of its wood demand from driftwood in most years.

Modeling results suggest that increased hydrologic variability may make the ability to harvest driftwood less predictable, and variations in the timing of flood events may become more inconvenient for rural Alaskans. Adaptations to these changing conditions include importing wood from other regions, which is not unprecedented, or enabling more Tanana residents to harvest wood when driftwood is mobilized. This might include providing financial loans to households to purchase or repair boats, recruiting more wood harvesters, and long-term wood storage. Another option includes gathering wood during the spring breakup, which is a far more dangerous activity. In some cases, Tanana residents have resorted to navigating through the ice and driftwood in search of good pieces of driftwood. This also requires more forethought because boats must be prepared at times when they are preoccupied with winter or other spring subsistence activities.

\section{Driftwood economics}

The economic analysis illustrates the potential reasons that one fuel source may be selected over another. Although modeling analyses indicate that the collection of standing deadwood is the cheapest option, these results will vary based on the actual location from which wood is collected. Additionally, modeling results do not take into account wear-related expenses on snow machines or boat motors. There is an inverse relationship between the times required to use different wood sources compared to fuel oil (Fig. 6). In a subsistence-based economy, it is assumed that most households would have a greater ability to use time resources over cash resources because of the limited availability of cash. Certain individuals in a village have jobs or other sources of a cash income. In these cases, it is assumed that there would be less flexibility to use time for subsistence activities, but cash resources may be substituted to obtain the necessary fuel supplies to be prepared for a winter in Alaska. In the case of Tanana, the city government and individual households use cash resources to purchase fuel oil or wood, depending on their needs. The economic analysis was performed at the community level, so differences in household or collective behaviors between households were not considered. Thus, the costs for the entire community were assessed over time.

\section{Model uncertainty}

There is uncertainty associated with each component of the model. The concept of a driftwood mobilization threshold is not a static entity, and at no point is there actually an unlimited amount of wood mobilized in the river. As mentioned previously, it is a useful assumption that assists in the study of a complex social-ecological system and during driftwood mobilization events, and it is reasonable that the driftwood supply far exceeds the demand by Tanana residents. However, the installation of wood-fired boilers is an increasing trend in remote Alaskan communities, so this assumption may become invalid if the demand for Yukon River driftwood continues to increase along the Yukon River. In time it may become necessary to allocate the driftwood resources by village to ensure that downriver needs are also met (Annear et al. 2004).

The driftwood mobilization threshold could be refined to represent the mobilization of driftwood more dynamically during high-flow or wind events. An assessment of the average village and household effort to collect driftwood would also be reasonable. Village and household demand is relatively predictable and could be modeled annually based on the local winter weather. Each input parameter in the economic model adds uncertainty to the model, but a reasonable effort was used to provide the best available estimates for each. Estimated fuel costs will change over time and could be updated or modeled. Wood deposition into the river could also be modeled in relation to permafrost thaw, bank erosion, or fire frequency.

\section{Model application}

By monitoring the USGS gauging station at Stevens Village, Tanana residents could utilize the driftwood mobilization threshold (Fig. 2) to gain lead time on driftwood runs, thus providing more predictability to an erratic system. Such tools 
would be useful for preparing for the driftwood harvest. The model cannot provide advance notification of driftwood flows, but it could use the driftwood mobilization threshold to infer that a driftwood run is not likely over the next few days. In some cases, the upstream social network informs Tanana residents about approaching driftwood runs, but more often, they rely only on their knowledge of the annual subsistence cycle.

\section{CONCLUSIONS}

The general principles illustrated by our research are applicable to river communities throughout the sub-Arctic, although glacially fed rivers have different hydrologic patterns. Driftwood is mobilized periodically during high-flow events. Subsistence users may or may not gather driftwood as a natural resource, but they likely follow similar subsistence cycles specific to their community.

The livelihood of Alaskan subsistence users is driven by subsistence cycles and is made more challenging by irregular environmental conditions. Increasing variability in climate cycles has serious consequences, which affect them financially and make them unavailable for other subsistence, cultural, or recreational activities. Tools that reduce the uncertainty associated with environmental variability are especially helpful for people who rely on natural and seasonal cycles. Our research demonstrates that scientists, in partnership with local stakeholders, have the capacity to develop these types of tools and suggests that regionalscale adaptations may help mitigate the impacts of climatic variability, while providing economic opportunities and energy independence in ways that increase stakeholders' adaptive capacity to environmental change.

Responses to this article can be read online at: http://www.ecologyandsociety.org/issues/responses. $\mathrm{php} / 7235$

\section{Acknowledgments:}

Our research was made possible by the generous partnership with the city of Tanana, Alaska, and the individuals that assisted with our research. We express our gratitude for the support and efforts of our collaborators, including Ruth Althoff, Charlie Campbell, Ronnie Evans, Tom Hyslop, Alfred Ketzler, and Charlie Wright. We thank Claire Alix, Charlie Campbell, Terry Chapin, Gary Kofinas, Amy Lovecraft, and two anonymous reviewers for their comments on the manuscript. Our research was supported by the National Science Foundation (NSF) Division of Polar Programs (grant numbers OPP-0422068, ARC-0517762, and ARRA ARC-0909517) and the NSF"Resilience and Adaptation of SocialEcological Systems in a Rapidly Changing North" IGERT program (grant number 0654441). Additional support was provided by the International Arctic Research Center, Alaska EPSCoR NSF grant number OIA-1208927 with the state of Alaska, Alaska Climate Science Center, University of Alaska Fairbanks (UAF) Water and Environmental Research Center, UAF Center for Global Change Student Research Grant, and the USGS through the National Institutes for Water Research program. The views expressed are those of the authors and do not represent the funding agencies.

\section{LITERATURE CITED}

Alix, C. 2005. Deciphering the impact of change on the driftwood cycle: contribution to the study of human use of wood in the Arctic. Global and Planetary Change 47:83-98. http://dx.doi. org/10.1016/j.gloplacha.2004.10.004

Alix, C., and K. Brewster. 2004. Not all driftwood is created equal: wood use and value along the Yukon and Kuskokwim Rivers, Alaska. Alaska Journal of Anthropology 2:2-19.

Alix, C., and D. Koester. 2002. Driftwood in the North Pacific: report of a driftwood sampling project undertaken on the Harriman expedition retraced. University of Alaska Fairbanks, Fairbanks, Alaska, USA.

Annear, T., I. Chisholm, H. Beecher, A. Locke, P. Aarrestad, C. Coomer, C. Estes, J. Hunt, R. Jocobson, G. Jobsis, J. Kauffman, J. Marshall, K. Mayes, G. Smith, R. Wentworth, and C. Stainaker. 2004. Instream flows for riverine resource stewardship. Revised edition. Instream Flow Council, Cheyenne, Wyoming, USA.

Arctic Climate Impact Assessment (ACIA). 2005. Arctic climate impact assessment. Cambridge University Press, New York, New York, USA.

Arctic Monitoring and Assessment Programme (AMAP). 2011. Snow, water, ice and permafrost in the Arctic (SWIPA): climate change and the cryosphere. AMAP, Oslo, Norway.

Berkes, F. 1999. Sacred ecology: traditional ecological knowledge and resource management. Taylor and Francis, Philadelphia, Pennsylvania, USA.

Berman, M., and G. Kofinas. 2004. Hunting for models: grounded and rational choice approaches to analyzing climate effects on subsistence hunting in an Arctic community. Ecological Economics 49:31-46. http://dx.doi.org/10.1016/j.ecolecon.2003.12.005

Berman, M., C. Nicolson, G. Kofinas, J. Tetlichi, and S. Martin. 2004. Adaptation and sustainability in a small Arctic community: results of an agent-based simulation model. Arctic 57:401-414. http://dx.doi.org/10.14430/arctic517

Brabets, T. P., and M. A. Walvoord. 2009. Trends in streamflow in the Yukon River Basin from 1944 to 2005 and the influence of the Pacific Decadal Oscillation. Journal of Hydrology 371:108-119. http://dx.doi.org/10.1016/j.jhydrol.2009.03.018

Brabets, T. P., B. Wang, and R. H. Meade. 2000. Environmental and hydrologic overview of the Yukon River Basin, Alaska and Canada. Water-Resources Investigations Report 99-4204. U.S. Geological Survey, Anchorage, Alaska, USA.

Carmack, E., and R. Macdonald. 2008. Water and ice-related phenomena in the coastal region of the Beaufort Sea: some parallels between native experience and Western science. Arctic 61:265-280.

Chapin, F. S., III, M. D. Robards, H. P. Huntington, J. F. Johnstone, S. F. Trainor, G. P. Kofinas, R. W. Ruess, N. Fresco, D. C. Natcher, and R. L. Naylor. 2006. Directional changes in ecological communities and social-ecological systems: a framework for prediction based on Alaskan examples. American Naturalist 168(S6):S36-S49. 
Cruikshank, J. 2001. Glaciers and climate change: perspectives from oral tradition. Arctic 54:377-393. http://dx.doi. org/10.14430/arctic795

Cullather, R. I., D. H. Bromwich, and M. C. Serreze. 2000. The atmospheric hydrologic cycle over the Arctic basin from reanalyses. Part I: comparison with observations and previous studies. Journal of Climate 13:923-937. http://dx.doi. org/10.1175/1520-0442(2000)013<0923:TAHCOT>2.0.CO:2

Druckenmiller, M. L., H. Eicken, J. C. George, and L. Brower. 2013. Trails to the whale: reflections of change and choice on an Iñupiat icescape at Barrow, Alaska. Polar Geography 36(1-2):5-29. http://dx.doi.org/10.1080/1088937X.2012.724459

Eicken, H., M. Kaufman, I. Krupnik, P. Pulsifer, L. Apangalook, P. Apangalook, W. Weyapuk Jr., and J. Leavitt. 2014. A framework and database for community sea ice observations in a changing Arctic: an Alaskan prototype for multiple users. Polar Geography 37(1):5-27. http://dx.doi.org/10.1080/1088937X.2013.873090

Fresco, N. 2006. Carbon sequestration in Alaska's boreal forest: planning for resilience in a changing landscape. University of Alaska Fairbanks, Fairbanks, Alaska, USA.

Fresco, N., and F. S. Chapin III. 2009. Assessing the potential for conversion to biomass fuels in interior Alaska. U.S. Forest Service Research Paper PNW-RP-579. U.S. Forest Service, Pacific Northwest Research Station, Portland, Oregon, USA.

Ge, S., D. Yang, and D. L. Kane. 2013. Yukon River Basin longterm (1977-2006) hydrologic and climatic analysis. Hydrological Processes 27:2475-2484.

Hinzman, L. D., N. D. Bettez, W. R. Bolton, F. S. Chapin, M. B. Dyurgerov, C. L. Fastie, B. Griffith, R. D. Hollister, A. Hope, H. P. Huntington, A. M. Jensen, G. J. Jia, T. Jorgenson, D. L. Kane, D. R. Klein, G. Kofinas, A. H. Lynch, A. H. Lloyd, A. D. McGuire, F. E. Nelson, W. C. Oechel, T. E. Osterkamp, C. H. Racine, V. E. Romanovsky, R. S. Stone, D. A. Stow, M. Sturm, C. E. Tweedie, G. L. Vourlitis, M. D. Walker, D. A. Walker, P. J. Webber, J. M. Welker, K. S. Winker, and K. Yoshikawa. 2005. Evidence and implications of recent climate change in northern Alaska and other Arctic regions. Climatic Change 72:251-298. http://dx.doi.org/10.1007/s10584-005-5352-2

Huntington, H. P. 2000. Using traditional ecological knowledge in science: methods and applications. Ecological Applications 10:1270-1274. http://dx.doi.org/10.1890/1051-0761(2000)010[1270: UTEKIS]2.0.CO;2

Huntington, H. P., S. Gearheard, A. R. Mahoney, and A. K. Salomon. 2011. Integrating traditional and scientific knowledge through collaborative natural science field research: identifying elements for success. Arctic 64:437-445. http://dx.doi. org/10.14430/arctic4143

Krupnik, I., and D. Jolly, editors. 2002. The Earth is faster now: indigenous observations of Arctic environmental change. Arctic Research Consortium of the United States, Fairbanks, Alaska, USA.

Lovecraft, A. L., and H. Eicken, editors. 2011. North by 2020. University of Alaska Fairbanks, Fairbanks, Alaska, USA.
Mason, O. K. 1998. The contest between the Ipiutak, Old Bering Sea, and Birnirk polities and the origin of whaling during the first millennium A.D. along Bering Strait. Journal of Anthropological Archaeology 17:240-325. http://dx.doi.org/10.1006/jaar.1998.0324

Nadasdy, P. 1999. The politics of TEK: power and the integration of knowledge. Arctic Anthropology 36:1-18.

Nicolson, C., M. Berman, C. T. West, G. P. Kofinas, B. Griffith, D. Russell, and D. Dugan. 2013. Seasonal climate variation and caribou availability: modeling sequential movement using satellite-relocation data. Ecology and Society 18(2): 1. http://dx. doi.org/10.5751/ES-05376-180201

Ott, R. A. 2000. Factors affecting stream bank and river bank stability, with an emphasis on vegetation influences. Pages 21-40 in M. W. Freeman, editor. Region III forest resources \& practices riparian management annotated bibliography. Report to the Alaska Board of Forestry. Alaska Department of Natural Resources, Division of Forestry, Anchorage, Alaska, USA, and Alaska Department of Fish and Game, Habitat and Restoration Division, Juneau, Alaska, USA.

Ott, R. A., M. A. Lee, W. E. Putman, O. K. Mason, G. T. Worum, and D. N. Burns. 2001. Bank erosion and large woody debris recruitment along the Tanana River, interior Alaska. Report to the Alaska Department of Environmental Conservation. Project No. NP-01-R9. Alaska Department of Natural Resources, Anchorage, Alaska, USA.

Pearce, T. D., J. D. Ford, G. J. Laidler, B. Smit, F. Duerden, M. Allarut, M. Andrachuk, S. Baryluk, A. Dialla, P. Elee, A. Goose, T. Ikummaq, E. Joamie, F. Kataoyak, E. Loring, S. Meakin, S. Nickels, K. Shappa, J. Shirley, and J. Wandel. 2009. Community collaboration and climate change research in the Canadian Arctic. Polar Research 28:10-27. http://dx.doi.org/10.1111/j.1751-8369.2008.00094. $\underline{\mathrm{x}}$

Prowse, T. D., B. R. Bonsal, C. R. Duguay, and M. P. Lacroix. 2007. River-ice break-up/freeze-up: a review of climatic drivers, historical trends and future predictions. Annals of Glaciology 46:443-451. http://dx.doi.org/10.3189/172756407782871431

Rowland, J. C., C. E. Jones, G. Altmann, R. Bryan, B. T. Crosby, L. D. Hinzman, D. L. Kane, D. M. Lawrence, A. Mancino, P. Marsh, J. P. McNamara, V. E. Romanovsky, H. Toniolo, B. J. Travis, E. Trochim, C. J. Wilson, and G. L. Geernaert. 2010. Arctic landscapes in transition: responses to thawing permafrost. Eos, Transactions American Geophysical Union 91:229-230. http://dx. doi.org/10.1029/2010EO260001

Schneider, W., S. Stephens, L. McCartney, K. Brewster, and M. Statscewich. 2013. Alaska stakeholders \& climate change. University of Alaska Fairbanks, Fairbanks, Alaska, USA. [online] URL: http://jukebox.uaf.edu/site/stakeholders

University of Alaska Fairbanks, Cooperative Extension Service (CES). 2008. Woodenergy content. CES, Fairbanks, Alaska, USA. [online] URL: http://www.alaskawoodheating.com/energy content. php

U.S. Census Bureau. 1980. Demographic data by city. U.S. Census Bureau, Washington, D.C., USA. 
U.S. Census Bureau. 2010. Demographic data by city. U.S. Census Bureau, Washington, D.C., USA.

Walvoord, M. A., and R. G. Striegl. 2007. Increased groundwater to stream discharge from permafrost thawing in the Yukon River basin: potential impacts on lateral export of carbon and nitrogen. Geophysical Research Letters 34:L12402. http://dx.doi. org/10.1029/2007GL030216

Weatherhead, E., S. Gearheard, and R. G. Barry. 2010. Changes in weather persistence: insight from Inuit knowledge. Global Environmental Change 20:523-528. http://dx.doi.org/10.1016/j. gloenvcha.2010.02.002

Wheeler, R., and C. Alix. 2004. Economic and cultural significance of driftwood in coastal communities of southwest Alaska. Report to the Cooperative Extension Services. University of Alaska Fairbanks, Fairbanks, Alaska, USA.

Wishart, R., and A. Murray. 2001. Report on driftwood use prepared for the Gwich'in Renewable Resource Board and Ross Wein, University of Alberta. Gwich'in Renewable Resource Board, Inuvik, Northwest Territories, Canada.

Yang, D., B. Ye, and D. L. Kane. 2004. Streamflow changes over Siberian Yenisei River basin. Journal of Hydrology 296:59-80. http://dx.doi.org/10.1016/j.jhydrol.2004.03.017

Yarie, J., L. A. Viereck, K. Van Cleve, and P. Adams. 1998. Flooding and ecosystem dynamics along the Tanana River. BioScience 48:690-695. http://dx.doi.org/10.2307/1313332 
Appendix 1. Driftwood economics model.

Appendix 1 provides details about the economics model and analyses presented in the paper above.

Table A1.1 defines the parameters used to estimate costs and identifies the source for the parameterization. The fuel equivalent $\left(D_{f u e l}\right)$ of each substitute fuel type used to meet any wood deficit (Defannual) was estimated based on specified proportions of each potential fuel type used as a driftwood substitute (\%fuel) in the entire village (Eqn. A1.1). The potential substitute fuel types include stranded driftwood, standing deadwood, and fuel oil.

$$
\text { Eqn. A1.1 } \quad D_{\text {fuel }}=\%_{\text {fuel }}\left(D e f_{\text {annual }}\right)
$$

Fuel $=$ stranded wood, standing wood, or fuel oil

The number of trips (Trip fuel) needed to gather sufficient stranded or standing wood to meet the village's demand $\left(D_{\text {fuel }}\right)$ for that fuel type were estimated from the amount of the fuel $\left(\mathrm{H}_{\text {fuel }}\right)$ that could be harvest on each trip (Eqn. A1.2). The financial costs (Cost $\left.t_{f u e l}\right)$ associated with the number of trips were also calculated. We used the number of trips, the mean travel distance $\left(\overline{D i s t}_{f u e l}\right)$, estimated miles traveled per gallon of gasoline $\left(M P G_{\text {vehicle }}\right)$, and the unit cost of gasoline (UnitCost gas $_{\text {) }}$ ). From this we subtracted the cost to harvest and process the equivalent amount of mobilized driftwood [based upon the villages annual driftwood deficit (Defannual $)$, the boats fuel consumption rate $\left.\left(G P H_{\text {drift }}\right]\right)$, the unit cost of gas, and the harvest rate for driftwood $\left.\left(H_{\text {drift }}\right)\right]$ (Eqn. A1.3).

Eqn. A1.2

$$
\operatorname{Trip}_{\text {fuel }}=D_{\text {fuel }} / H_{\text {fuel }}
$$

Fuel $=$ stranded or standing wood

Eqn. A1.3

$$
\begin{aligned}
\text { Cost }_{\text {fuel }}=\left\{\text { Trip }_{\text {fuel }}\left[\frac{\overline{\text { Dist }}_{\text {fuel }}}{M P G_{\text {vehicle }}}\right] \text { UnitCost }_{\text {gas }}\right\} \\
-\left\{\frac{\text { Def } f_{\text {annual }} G P H_{\text {drift }} \text { UnitCost }_{\text {gas }}}{H_{\text {drift }}}\right\}
\end{aligned}
$$

Fuel $=$ stranded or standing wood

The amount of time required to collect and process (cut, split, and stack) sufficient wood $\left(\right.$ Time $\left._{\text {fuel }}\right)$ to meet the village needs were calculated from number of trips, estimated time per trip $\left(\overline{\text { Time }}_{\text {trip }}\right)$, number of people per trip (People trip), village demand for that fuel type, estimated time for processing $\left(\overline{\text { Time }}_{\text {process }}\right)$, and estimated number of people involved in processing (People process $)$ ]. From this we subtracted the estimated time to collect and process the equivalent amount of mobilized driftwood [calculated from estimates of driftwood harvest rate $\left(H_{\text {drift }}\right)$, time required for harvesting driftwood $\left(\overline{\text { Trme }}_{\text {drift }}\right)$, and the number of people involved in the harvest of driftwood (People drift $)$ ] (Eqn. A1.4). 
Eqn. A1.4 Time $_{\text {fuel }}=\left\{\right.$ Trip $_{\text {fuel }} \overline{\text { Trme }}_{\text {trip }}$ People trip $+D_{\text {fuel }} \overline{\text { Tlme }}_{\text {process }}$ People process $\}$ $-\left\{H_{\text {drift }} \overline{\text { Time }}_{\text {drift }}\right.$ People drift $\}$

Fuel $=$ stranded wood or standing wood

Additionally, the cost of using fuel oil $\left(\right.$ Cost $\left._{\text {oil }}\right)$ to meet the equivalent energy demand $\left(D_{\text {oil }}\right)$ of the village was calculated using the energy equivalent of fuel oil relative to driftwood (Equiv oil $\left._{\text {il }}\right)$ and the unit cost of fuel oil (UnitCost ${ }_{\text {oil }}$ ) (Eqn. A1.5).

Eqn. A1.5 $\quad$ Cost $_{\text {oil }}=D_{\text {oil }}$ Equiv $_{\text {oil }}$ UnitCost $_{\text {oil }}$

Estimates of the total financial and temporal costs were also calculated (Eqn. A1.7 and Eqn. A1.8) by summing the individual costs for each fuel type.

Eqn. A1.7

$$
\text { Cost }_{\text {total }}=\text { Cost }_{\text {stranded }}+\text { Cost }_{\text {standing }}+\text { Cost }_{\text {oil }}
$$

Eqn. A1.8

Time $_{\text {total }}=$ Time $_{\text {stranded }}+$ Time $_{\text {standing }}+$ Time $_{\text {oil }}$ 
Table A1.1. Input and output parameters for the economic analyses of the driftwood harvest alternatives.

\begin{tabular}{|c|c|c|c|}
\hline & Parameter & Symbol & Assigned value \\
\hline \multirow{9}{*}{ 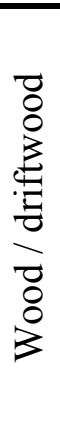 } & Deficit (cords) & $\overline{\text { Defannual }}$ & 903 \\
\hline & Demand (cords equivalent) & $\mathrm{D}_{\text {fuel }}$ & Calculated \\
\hline & Harvest rate (mobilized driftwood, cord/ hour) & $\mathrm{H}_{\text {drift }}$ & 0.25 \\
\hline & People (number during driftwood harvest) & People $_{\text {drift }}$ & 2 \\
\hline & Processing rate (cut and split) (cord/hour) & Time $_{\text {process }}$ & 0.5 \\
\hline & Processing people (person) & People $_{\text {process }}$ & 2 \\
\hline & Gallons per hour (boat) & $\mathrm{GPH}_{\text {drift }}$ & 1 \\
\hline & Estimated economic costs - driftwood & Cost $_{\text {drift }}$ & Calculated \\
\hline & Time estimate - harvest and process (hours) & Time $_{\text {drift }}$ & Calculated \\
\hline \multirow{10}{*}{ 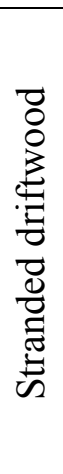 } & Deficit replacement from stranded driftwood (\%) & $\%$ stranded & 25 \\
\hline & Average round trip miles traveled for stranded driftwood & Dist $_{\text {stranded }}$ & 3 \\
\hline & Boat fuel economy (miles / gallon) & $\mathrm{MPG}_{\text {vehicle }}$ & 2 \\
\hline & Gas costs (\$/gallon) & Cost $_{\text {gas }}$ & $\$ 6.85$ \\
\hline & People (number / trip) & People $_{\text {trip }}$ & 3 \\
\hline & Harvest rate (Cords stranded driftwood / trip) & $\mathrm{H}_{\text {stranded }}$ & 1 \\
\hline & Average time (hour / trip) & Time $_{\text {trip }}$ & 8 \\
\hline & Number of trips - stranded driftwood & trip $_{\text {stranded }}$ & Calculated \\
\hline & Estimated economic costs - stranded driftwood & Cost $_{\text {stranded }}$ & Calculated \\
\hline & Time estimate (man-hours) & Time stranded & Calculated \\
\hline \multirow{10}{*}{ 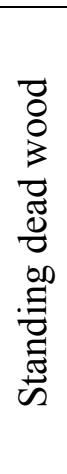 } & Deficit replacement from standing wood (\%) & $\%$ standing & 25 \\
\hline & Average round trip miles traveled for standing wood & Dist $_{\text {standing }}$ & 2 \\
\hline & Snow machine fuel economy (miles / gallon) & $\mathrm{MPG}_{\text {vehicle }}$ & 7 \\
\hline & Gas costs (\$/gallon) & Cost $_{\text {gas }}$ & $\$ 6.85$ \\
\hline & People (number / trip) & People $_{\text {trip }}$ & 2 \\
\hline & Harvest rate (Cords standing wood / trip) & $\mathrm{H}_{\text {standing }}$ & 0.3 \\
\hline & Average time (hour / trip) & Time $_{\text {trip }}$ & 4 \\
\hline & Number of trips - standing wood & trip $_{\text {standing }}$ & Calculated \\
\hline & Estimated economic costs - standing wood & Cost $_{\text {standing }}$ & Calculated \\
\hline & Time estimate (man-hours) & Time standing & Calculated \\
\hline \multirow{5}{*}{$\begin{array}{l}=\overline{0} \\
\frac{0}{\overrightarrow{1}} \\
\text { I }\end{array}$} & $\%$ fuel oil replacement & $\%_{\text {oil }}$ & 45 \\
\hline & Gallons equivalent (Gallons fuel oil / cord) & Equiv $_{\text {oil }}$ & $122 \dagger$ \\
\hline & Fuel oil costs: (\$/gallon) & UnitCost $_{\text {oil }}$ & $\$ 6.00$ \\
\hline & Estimated Fuel costs & Cost $_{\text {oil }}$ & Calculated \\
\hline & Time estimate (man-hours) & Time $_{\text {oil }}$ & Calculated \\
\hline \multirow{2}{*}{ 宽 } & Total Economic Costs & Cost $_{\text {total }}$ & Calculated \\
\hline & Total Time Investment (man-hours) & Time $_{\text {total }}$ & Calculated \\
\hline
\end{tabular}

$\dagger$ (USDA Cooperative Extension Service 2008) 